\title{
KONSEPSI KEADILAN DALAM PERLINDUNGAN SAKSI DAN KORBAN
}

\author{
Hardianto Djanggih \\ Universitas Tompotika Luwuk Banggai
}

\begin{abstract}
Abstrak
Tujuan hukum pidana adalah melindungi warga negara dari ancaman pelaku-pelaku tindak pidana. Perlindungan tersebut haru terwujud dalam dimensi keadilan bagi saksi dan korban. Prinsip keadilan dalam bentuk tanggungjawab negara kepada korban karena akibat gugurnya tanggungjawab pelaku menjalankan pemidanaan pada dasarnya adalah memberikan keadilan melalui penegakan hukum pidana oleh negara. Perlindungan kepada korban tindak pidana merupakan bagian dari perlindungan hukum bagi warga negara Indonesia. Keadilan diwujudkan negara bagi korban tindak pidana tersebut didasari dan dijiwai oleh hakikat keadilan.
\end{abstract}

\section{Kata Kunci: Keadilan, Perlindungan, Saksi, Korban}

\section{Pendahuluan}

Keadilan seharusnya diwujudkan negara bagi korban tindak pidana tersebut didasari dan dijiwai oleh hakikat keadilan kemanusiaan yaitu keadilan dalam hubungannya manusia dengan dirinya sendiri, manusia dengan manusia lainnya, manusia dengan masyarakat, bangsa dan negara serta hubungan manusia dengan tuhannya. Hukum yang adil merupakan sisi aktif ideologi. Peranan hukum dalam memperkuat ideologi yang berlaku di masyarakat tertentu. ${ }^{1}$

Suatu kaidah hukum khususnya keadilan dalam tanggungjawab negara kepada korban tindak pidana dapat dikatakan berlaku secara filosofis apabila kaidah itu sesuai atau tidak bertentangan cita-cita hukum suatu masyarakat falsafah hidup masyarakat Indonesia, misalnya yang dijadikan ukuran tertentunya adalah Pancasila yang dalam studi hukum dikenal dengan sumber dari segala sumber hukum. ${ }^{2}$ Pandangan Arief Gosita menyatakan bahwa ada korban ada kejahatan, ada kejahatan pasti ada

${ }^{1}$ Colin Sumner, Reading Ideologis. An Investigation into Marxist Theory of Ideologi and Law (Academic Press 1979).[5];Petrus C.K.L. Bello, Ideologi Hukum, Refleksi Filsafat Atas Ideologi Di Balik Hukum (Insan Merdeka 2013). hlm.33

2 Jimly Asshiddiqie., Pembahuran Hukum Pidana Indonesia (Angkasa 1996). Hlm.12- 13 
korbann, jika ingin mencegah terjadiya kejahatan maka jangan mengabaikan adanya korban. Jika demikian maka korban harus menjadi perhatian khusus dalam terjadinya suatu kejahatan. ${ }^{3}$

Perlindungan kepada korban tindak pidana merupakan bagian dari perlindungan hukum bagi warga negara Indonesia. Hak untuk mendapatkan keadilan oleh korban merupakan hak asasi yang sangat mendasar dimana setiap orang berhak atas pengakuan, jaminan, perlindungan dan perlakuan hukum yang adil serta mendapat kepastian hukum dan perlakuan yang sama di depan hukum. Setiap orang diakui sebagai manusia pribadi yang berhak menuntut dan memperoleh perlakuan serta perlindungan yang sama sesuai dengan martabat kemanusiaannya di depan hukum. Dalam merumuskan prinsip-prinsip perlindungan hukum bagi rakyat (di Indonesia) landasan pijak kita adalah Pancasila sebagai dasar ideologi dan dasar falsafah negara. ${ }^{4}$

Tujuan penegakan hukum pidana dengan dipidananya seorang pelaku tindak pidana oleh negara diantaranya adalah untuk memperbaiki sikap pelaku dan memberikan penderitaan atas perbuatannya serta mempertahankan tertib masyarakat. ${ }^{5}$ Koeswadji mengemukakan bahwa tujuan pokok dari pemidanaan yaitu ${ }^{6}$ mempertahankan ketertiban masyarakat (dehandhaving van de maatschappelijkeorde); memperbaiki kerugian yang diderita oleh masyarakat sebagai akibat dari terjadinya kejahatan. (het herstel van het doer de misdaad onstane maatschappelijke nadeel); memperbaiki si penjahat (verbetering vande dader); membinasakan si penjahat (onschadelijk maken van de misdadiger); mencegah kejahatan (tervoorkonning van de misdaad).

${ }^{3}$ Didik Endro Purwoleksono, 'Tindak Pidana Di Bidang Merek Dan Jenis Sanksinya' (2005) 20 Yuridika. Hlm.281.

4 Philipus M. Hadjon, Perlindungan Hukum Bagi Rakyat Indonesia, Sebuah Studi Tentang Prinsip-Prinsipnya, Penanganannya Oleh Pengadilan Dalam Lingkungan Peradilan Umum Dan Pembentukan Peradilan Administrasi Negara (PT Bina Ilmu 1987).hlm.19

${ }^{5}$ E. Utrecht, Hukum Pidana I (Universitas Jakarta 1958).hlm.157

6 Koeswadji, Perkembangan Macam-Macam Pidana Dalam Rangka Pembangunan Hukum Pidana (Citra Aditya Bhakti 1995).hlm.12 
Dipidananya pelaku tidak berarti kewajiban negara memberikan keadilan terhadap korban selesai. ${ }^{7}$ Negara dapat mencegah terjadinya main hakim sendiri “eigenrichting" (mengadili sendiri). Hal yang lebih penting dalam penegakan hukum pidana oleh negara adalah negara harus memikirkan apa manfaat dipidananya seorang pelaku pidana bagi korbannya, dan tidak hanya itu negara juga harus memberikan keadilan bagi korban jika telah terjadi tindak pidana tetapi pelaku tidak dapat menjalani pidananya atau tidak dipidana.

Pemidanaan atau dipidananya pelaku tidak terlepas dari masalah pertanggungan jawab pidana yang erat sekali hubungannya dengan masalah keadilan. Pertanggungan jawab pidana sebagai soal hukum pidana terjalin dengan keadilan sebagai soal filsafat. ${ }^{8}$ Negara menjamin bahwa pelaku tindak pidana harus diberi imbalan yang setimpal sesuai dengan sanksi dari aturan yang dilanggar tersebut. Permasalahan keadilan yang muncul terhadap korban adalah bagaimana jika pelaku tidak dapat menjalakan pidana yang jatuhkan oleh negara karena hapusnya hak menuntut dan hilangnya hak menjalankan pidana.

Apabila suatu peristiwa pidana terjadi, aturan hukum sering kali memfokuskan diri untuk menghukum pelaku kejahatan sehingga sering kali korban dari kejahatan tersebut terabaikan. Dampak kejahatan menimbulkan korban dan kerugian. Kerugian yang timbul itu bisa diderita oleh korban sendiri, maupun oleh pihak lain secara tidak langsung. ${ }^{9}$ Perkembangan keadilan dalam sitem peradilan pidana, sudah seharusnya mulai mengarah kepada bentuk tanggungjawab negara untuk menjamin dan memastikan bahwa korban mendapatkan keadilan yang diinginkannya atas tindak pidana yang menimpanya. Permasalahan berikutnya yang timbul adalah apa bentuk keadilan yang diberikan kepada korban oleh negara, apakah menjadi tanggungjawab negara atau tanggungjawab keluarga pelaku atau ahli waris pelaku.

7 Perdana Eliakhim Manalu; Suhaidi; Hamdan; Hasim Purba, 'Sanksi Pidana Terhadap Pelaku Tindak Pidana Perdagangan Orang (Studi Beberapa Putusan Pengadilan Negeri Di Indonesia)' (2014) 2 USU Law Jurnal.hlm.176-189

8 Roeslan Saleh, Pikiran-Pikiran Tentang Pertanggungan Jawab Pidana (Ghalia Indonesia 1982).hlm.10

9 J.E Sahetapy, Viktimologi Sebuah Bunga Rampai (Pustaka Sinar Harapan 1987).hlm.36 


\section{Pembahasan}

Tujuan penghukuman agar pelaku tidak mengulangi perbuatannya dan dibina sehingga dapat kembali kepada masyarakat saja juga tidak dapat menjadi penyeimbang terhadap keadilan bagi korban. Korban suatu kejahatan tidaklah selalu harus berupa individu atau orang perorangan, tatapi bisa juga kelompok orang, masyarakat atau juga badan hukum bahkan negara. ${ }^{10}$ Keadilan bagi korban setidaknya dapat diwujudkan dengan dihukumnya pelaku, tetapi negara secara formil dan materil masih belum dapat memberikan keadilan bagi korban jika pelaku pidana tidak dapat menjalankan pidananya karena hapusnya hak menuntut dan hilangnya hak menjalankan pidana.

Beberapa pemahaman apa yang dimaksud dengan korban adalah sebagai berikut Kitab Undang-Undang Hukum Acara Pidana (KUHAP) tidak terdapat pengertian mengenai korban namun di dalam UU No. 13 Tahun 2006 pada Pasal 1 angka 2 menyebutkan bahwa korban adalah seorang yang mengalami penderitaan fisik, mental dan/atau kerugian ekonomi yang diakibatkan oleh suatu tindak pidana. Muladi memberikan pengertian tentang korban (victims) yaitu orang-orang yang baik secara individual maupun kolektif telah menderita kerugian, termasuk kerugian fisik atau mental, emosional, ekonomi, atau gangguan substansial terhadap hakhaknya yang fundamental, melalui perbuatan atau komisi yang melanggar hukum pidana dimasing-masing negara termasuk penyalahgunaan kekuasaan. ${ }^{11}$

Arief Gosita memberikan pengertian tentang korban adalah mereka yang menderita jasmaniah dan rohaniah sebagai akibat tindakan orang lain yang mencari pemenuhan kepentingan diri sendiri atau yang bertentangan dengan kepentingan hak asasi pihak yang menderita. ${ }^{12}$ Pendapat yang tidak jauh berbeda, Ralp de Sola memberikan pengertian bahwa korban (victim) adalah "person who has injured mental or physical suffering, los of property or death resulting from an actual or

10 Didik M. Arife Mansur dan Elisatris Gultom, Urgensi Perlindungan Korban Kejahatan, Antara Norma Dan Realita (PT Raja Grafindo Persada 2007).hlm.45.

${ }_{11}$ Muladi, Hak Asasi Manusia: Hakekat, Konsep Dan Implikasinya Dalam Perspektif Hukum Dan Masyarakat (Refika Aditama 2005).[108].;Didik M. Arife Mansur dan Elisatris Gultom.Op.Cit. hlm.47

12 Arief Gosita, Masalah Korban Kejahatan: Kumpulan Karangan (Akademika Perseindo 1983).hlm.41. 
attempted criminal offense committed by anoteher"54 (orang yang mengalami penderitaan mental atau fisik, kehilangan harta benda atau meninggal yang disebabkan oleh perbuatan nyata atau upaya tindakan kriminal yang dilakukan oleh orang lain).

Berdasarkan pada konteks yang berbeda di didalam Undang-Undang No. 23 Tahun 2004 Tentang penghapusan kekerasan dalam rumah tangga, pengertian tentang korban terdapat dalam Pasal 1 angka 3 yaitu korban adalah orang yang mengalami kekerasan dan/atau ancaman kekerasan dalam lingkup rumah tangga. Pasal 1 angka 2 Peraturan Pemerintah No. 2 Tahun 2002 Tentang tatacara perlindungan terhadap korban dan saksi dalam pelanggaran hak asasi manusia yang berat lebih terfokus ke memberikan pengertian tentang korban yaitu orang perseorangan atau kelompok orang yang mengalami penderitaan sebagai akibat pelanggaran hak asasi manusia yang berat yang memerlukan perlindungan fisik dan mental dari ancaman, gangguan, teror, dan kekerasan dari pihak manapun.

Pengertian korban menurut deklarasi Perserikatan Bangsa-Bangsa (PBB) dalam kongres PBB VII Tahun 1985 di Milan tentang The Prevention of Crime and the Treatment of Offenders, meberikan pngertian korban yaitu:

"victim means person who, individually or collectively, have suffered harm, including physical or mental injury, emotional suffering, ecoNomic loss or substantial impairment of their fundamental right, through acts omission of criminal laws operative within member states, including those laws proscribing criminal abuse of power' through acts or omissions that do Not yet constitute violations of national criminal laws but of internationally recognized Norms relating to human rights". ${ }^{13}$

Berdasarkan pengertian korban di atas pelaku bisa saja orang dan badan hukum bahkan negara, pengertian tersebut tidak menunjukkan apakah suatu badan hukum juga dapat menjadi korban dan menuntut hak-haknya atas perbuatan yang merugikan badan hukum tersebut karena badan hukum juga merupakan subjek hukum dan bahkan dalam tindak pidana juga dapat dipersangkakan badan hukum tersebut sebagai pelaku yang dapat dijatuhi dipidana.

13 Romli Atmasasmita, Masalah Santunan Korban Kejahatan (BPHN).[9];Didik M. Arife Mansur dan Elisatris Gultom.hlm.46 
Dalam Declaration Of Basic Principles OfJustice For Victim Of Crime And The Abuse Of Power (Deklarasi Prinsip-Prinsip Dasar Keadilan Bagi Korban Kejahatan dan Penyalahgunaan Kekuasaan) menyatakan bahwa korban kejahatan harus diperlakukan dengan penuh perhatian dan rasa hormat terhadap martabatnya, serta diberi hak untuk segera menuntut ganti rugi (kalau ada aturannya), mekanisme hukum dan administrasinya harus dirumuskan dan disahkan untuk memungkinkan korban kejahatan memperoleh ganti rugi. Jika ganti rugi yang menyeluruh tidak dapat diperoleh dari pelaku kenakalan, dalam kasus-kasus kerugian fisik atau mental yang parah, negara berkewajiban memberi ganti rugi kepada korban kejahatan atau keluarganya. $^{14}$

Hakikat kebenaran adalah keadilan atau justice, tegaknya kebenaran menurut hukum adalah tegaknya keadilan menurut hukum. Kebenaran dan keadilan menurut hukum adalah penegakan hukum tanpa diskriminasi, penegakan hukum tanpa mempersoalkan akibat hukum yang diterapkan, menyenangkan atau tidak menyenangkan dan berdasarkan pada esensial manusia. Tanggungjawab negara kepada korban di Indonesia dari aturan yang ada menunjukan adanya pembedaan tanggungjawab negara kepada korban dalam hal tersangka tidak bertanggungjawab secara pidana atau tidak menjalani hukumannya yaitu terbatas pada korban yang dinyakan secara implisit dalam peraturan perundang-undangan saja. Sebagaimana dinyatakan dalam UU Nomor 13 Tahun 2006 bahwa negara memberikan kompensasi kepada korban tindak pidana HAM berat, sedangakan dalam PP Nomor 44 Tahun 2008 menyatakan bahwa kompensasi adalah adalah ganti kerugian yang diberikan oleh negara karena pelaku tidak mampu memberikan ganti kerugian sepenuhnya yang menjadi tanggung jawabnya.

Sebagai contohnya seorang yang ingin membelikan obat untuk anaknya yang sekarat, dalam perjalanan dirampok oleh seorang sehingga dia tidak dapat menyelamatkan anaknya. Tindakan jahat tersebut merupakan tindak pidana pencurian atau perampasan atau tindak pidana biasa, tetapi bagi korban pencurian merupakan penderitaan yang sangat dalam, dengan dicuri uang miliknya dan uang itu hanya satusatunya yang ia miliki sehingga waktu yang sangat singkat harus menyelamatkan

14 Kunarto, PBB Dan Pencegahan Kejahatan, Ikhtisar Implementasi Hak Asasi Manusia Dalam Penegakan Hukum (Cipta Manunggal 1996).hlm.107. 
anaknya, tidak dapat dicapainya. Atas hal tersebut tidak ada upaya yang dapat dilakukannya untuk menuntuk pertanggungjawaban negara dalam hal pelaku tidak tertangkap, atau tertangkap tetapi melarikan diri sampai lampau waktu/ daluwarsa, atau dalam tahap penyidikan, atau penuntutan atau persidangan pelaku terkena penyakit jiwa atau gila. Pada dasarnya kejahatan apa pun pasti melanggar HAM, tetapi kompensasi yang diberikan negara hanya kepada pelanggaran HAM berat yaitu Pembunuhan massal (genocide), pembunuhan sewenang-wenang atau di luar putusan pengadilan (arbitrary/extra judicial killing), penyiksaan, penghilangan orang secara paksa, perbudakan, atau diskriminasi yang dilakukan secara sistematis (systematic diserimination) tanpa dasar pertimbangan apakah pelaku dapat bertanggungjawab terhadap restitusi atau tidak. Hal tersebut jelas melanggar asas equality before the law.

Perlindungan hukum terhadap korban oleh negara masih diukur berdasarkan ganti kerugian dalam bentuk kompensasi oleh negara padahal tidak semua bentuk tanggung jawab negara kepada korban hanya di ukur oleh materi semata. Negara masih belum mempunyai konsep yang jelas terhadap korban dalam hal tujuan pemidanaan oleh negara tidak tercapai. Dalam tindak pidana tertentu yang mensyaratkan perlu adanya laporan atau kesaksian atau kerugian yang dialami maka korban akan lebih baik memilih menggugat secara perdata, karena yang akan diberikan adalah hanya ganti kerugian.

Tanggungjawab negara kepada korban juga tidak terlepas dari adanya reformasi konstitusi. Reformasi konstitusi tersebut didasarkan pada argumen bahwa konstitusi merupakan kumpulan prinsip-prinsip yang mengatur kekuasaan pemerintah, hak-hak yang diperintah dan hubungan antar keduanya. ${ }^{15}$ Ahamad Kamil dan M. Fauzan menyatakan bahwa: "Asas persamaan kedudukan ini, sangat penting ditegakan terutama dalam kehidupan bermasyarakat yang majemuk, tujuannya adalah 1. Untuk melenyapkan perlakuan diskriminasi katagoris dan diskriminasi normative dalam penegakan hukum; 2. Dengan demikian tidak ada perbedaan perlakuan hukum berdasar perbedaan jenis kelamin, etnis, pendidikan dan status sosial ekonomi. Juga tidak boleh ada perbedaan penerapan hukum yang diperlakukan dan diterapkan berdasarkan perbedaan jenis kelamin, etnis, pendidikan dan status sosial ekonomi.

15 C.F. Strong, Modern Political Constitution (Sidgwick and Jackson 1960).hlm. 10 
Semua sama di depan hokum; 3. Lebih lanjut kaidah "equality be fore the law" berbarengan langsung dengan tuntutan jaminan penegakan: a. Yakni memberi perlindungan yang sama di depan hukum (equal protection on the law). B. Equal justice under the law, yakni member perlakuan yang sama adilnya menurut hukum". ${ }^{16}$

\section{Kesimpulan}

Prinsip keadilan dalam bentuk tanggungjawab negara kepada korban karena akibat gugurnya tanggungjawab pelaku menjalankan pemidanaan pada dasarnya adalah memberikan keadilan melalui penegakan hukum pidana oleh negara. Tidak seharusnya negara hanya membiarkan korban memperjuangkan keadilan bagi dirinya melalui upaya hukum lain secara perdata, dan atau hanya bertanggung jawab terhadap kerugian berupa kompensasi kepada korban bila pelaku tidak dapat memberikan ganti rugi atau restitusi. Jika demikian halnya maka negara harus memberikan kompensasi kepada ribuan korban yang pelakunya tidak menjalani pemidanaan yang pastinya tidak dapat memberikan restitusi kepada korban. Konsep keadilan sebagai tanggungjawab negara kepada korban seharusnya bersifat khusus dengan tidak terbatas pada membeda-bedakan korban dari jenis tindak pidana yang dialaminya.

16 H. Ahmad Kamil dan M. Fauzan, Kaidah-Kaidah Hukum Yurisprudensi (Kencana Prenada Media Group 2008).hlm.21 


\section{DAFTAR PUSTAKA}

Colin Sumner, Reading Ideologis. An Investigation into Marxist Theory of Ideologi and Law (Academic Press 1979).[5];Petrus C.K.L. Bello, Ideologi Hukum, Refleksi Filsafat Atas Ideologi Di Balik Hukum (Insan Merdeka 2013).

Jimly Asshiddiqie., Pembahuran Hukum Pidana Indonesia (Angkasa 1996).

Didik Endro Purwoleksono, 'Tindak Pidana Di Bidang Merek Dan Jenis Sanksinya' (2005) 20 Yuridika.

Philipus M. Hadjon, Perlindungan Hukum Bagi Rakyat Indonesia, Sebuah Studi Tentang Prinsip-Prinsipnya, Penanganannya Oleh Pengadilan Dalam Lingkungan Peradilan Umum Dan Pembentukan Peradilan Administrasi Negara (PT Bina Ilmu 1987).

E. Utrecht, Hukum Pidana I (Universitas Jakarta 1958).

Koeswadji, Perkembangan Macam-Macam Pidana Dalam Rangka Pembangunan Hukum Pidana (Citra Aditya Bhakti 1995).

Perdana Eliakhim Manalu; Suhaidi; Hamdan; Hasim Purba, 'Sanksi Pidana Terhadap Pelaku Tindak Pidana Perdagangan Orang (Studi Beberapa Putusan Pengadilan Negeri Di Indonesia)' (2014) 2 USU Law Jurnal.

Roeslan Saleh, Pikiran-Pikiran Tentang Pertanggungan Jawab Pidana (Ghalia Indonesia 1982).

J.E Sahetapy, Viktimologi Sebuah Bunga Rampai (Pustaka Sinar Harapan 1987).

Didik M. Arife Mansur dan Elisatris Gultom, Urgensi Perlindungan Korban Kejahatan, Antara Norma Dan Realita (PT Raja Grafindo Persada 2007).

Muladi, Hak Asasi Manusia: Hakekat, Konsep Dan Implikasinya Dalam Perspektif Hukum Dan Masyarakat (Refika Aditama 2005).[108].;Didik M. Arife Mansur dan Elisatris Gultom.

Arief Gosita, Masalah Korban Kejahatan: Kumpulan Karangan (Akademika Perseindo 1983).

Romli Atmasasmita, Masalah Santunan Korban Kejahatan (BPHN).[9];Didik M. Arife Mansur dan Elisatris Gultom.

Kunarto, PBB Dan Pencegahan Kejahatan, Ikhtisar Implementasi Hak Asasi Manusia Dalam Penegakan Hukum (Cipta Manunggal 1996).

C.F. Strong, Modern Political Constitution (Sidgwick and Jackson 1960).

Ahmad Kamil dan M. Fauzan, Kaidah-Kaidah Hukum Yurisprudensi (Kencana Prenada Media Group 2008).hlm.21

Djanggih, H., \& Ahmad, K. (2017). The Effectiveness of Indonesian National Police Function on Banggai Regency Police Investigation (Investigation Case Study Year 2008-2016), Jurnal Dinamika Hukum. 17 (2), 152-157. 
Thalib, H., Rahman, S., Mamulai, S., \& Djanggih, H. (2017). Verification Through the Electronic Media (Teleconference) on the Court in Criminal Judicial System. ADRI International Journal Of Law and Social Science, 1 (1), 1-9.

Djanggih, H. \& Saefudin Y. (2017). Pertimbangan Hakim pada Putusan Praperadilan: Studi Putusan Nomor: 09/PID. PRA/2016/PN. Lwk Tentang Penghentian Penyidikan Tindak Pidana Politik Uang. Jurnal Penelitian Hukum De Jure. 17 (3), 413-423.

Djanggih, H. (2013). Kebijakan Hukum Pidana Dalam Penanggulangan Cybercrime di Bidang Kesusilaan. Jurnal Media Hukum, 1 (2), 57-77.

Qamar, N., \& Djanggih, H. (2017). Peranan Bahasa Hukum dalam Perumusan Norma Perundang-undangan. Jurnal Imiah Kebijakan Hukum. 11 (3), 337-347.

Djanggih, H., \& Salle. (2017). Aspek Hukum Pengadaan Tanah bagi Pelaksanaan Pembangunan untuk Kepentingan Umum, Pandecta; Research Law Journal, 12 (2), 165-172.

Mamulai, M., Djanggih, H \& Wahab, M. (2017). Strength of Evidence of Electronic Media (Teleconference) In The Criminal Justice System, VRIJSPRAAK; International Law Journal, 1 (1), 1-20.

Thalib, H., Ramadhan, A., \& Djanggih, H. (2017). The Corruption Investigation In The Regional Police of Riau Islands, Indonesia, Rechtsidee, 4 (1).

Ahmad, K. \& Djanggih. H. (2017). Batasan Penerapan Asas Persidangan Terbuka Untuk Umum Dalam Siaran Persidangan Pidana Oleh Media, Jurnal Hukum Ius Quia Iustum, 24 (3). 488-505. 